\title{
RANCANG BANGUN SISTEM PERJALANAN DINAS SEKRETARIAT DPRD PROVINSI JAWA BARAT
}

\author{
Peti Savitri ${ }^{1)}$, Imani Siti Amaliah ${ }^{2)}$ \\ Teknik Informatika ${ }^{1), 2)}$ \\ Universitas Sangga Buana YPKP $^{1)}$, ST INTEN ${ }^{2)}$ \\ petisavitri@gmail.com ${ }^{1)}$, imanisitiamaliah@gmail.com ${ }^{2)}$
}

\begin{abstract}
ABSTRAK
Kegiatan perjalanan dinas PNS (Pegawai Negeri Sipil) dan Anggota DPRD Provinsi Jawa Barat merupakan salah satu kegiatan yang sering dilakukan. Pemberkasan dalam kegiatan perjalanan dinas yang sedang berjalan masih dinilai rentan terhadap masalah dalam pemberkasan dan pencarian. Guna membantu staf administrasi yang mengurus perjalanan dinas, maka penelitian ini dibuat. Penelitian ini menggunakan metode waterfall dalam pengembangan sistemnya yang meliputi tahapantahapan analisis dan definisi, perancangan sistem, implementasi dan pengujian unit, integrasi dan pengujian sistem, operasi dan pemeliharaan. Sedangkan pengumpulan data dilakukan dengan cara observasi, wawancara, studi pustaka, dan pengumpulan data manual. Pemodelan sistem yang digunakan adalah bahasa pemodelan UML (Unified Modeling Language) dan berbasis web dengan bahasa pemrograman PHP (Hypertext Preprocessor) dan database mysql. Hasil penelitian ini dapat mempermudah seluruh bagian yang terkait dengan kegiatan perjalanan dinas baik dalam pembuatan nota dan surat tugas, surat perintah, laporan pengontrolan kendali surat perintah perjalanan dinas.
\end{abstract}

Kata kunci : Pemberkasan, perjalan dinas, pemodelan, UML, sistem.

\section{PENDAhuluaN}

Dalam dunia teknologi yang semakin maju ini, banyak dari instansi pemerintahan yang berskala kecil, menengah ataupun besar menerapakan berbagai tekonolgi informasi untuk mendukung seluruh kegiatan dalam instansi nya. Hal ini diterapkan agar instansi dapat meningkatkan kinerja yang efektif dan efiesien dalam mengopersionalkan instansi nya. Sehingga dihasilkan informasi yang akurat, cepat dan tepat. Penerapan dari teknologi ini, tidak terlepas dari mekanisme komputerisasi (software dan hardware). Dengan menggunakan mekanisme ini, pada mulanya sistem yang masih manual dirubah menjadi sistem yang otomatis terintegrasi yaitu menggunakan komputer. Banyak sistem yang masih manual yang dipakai di banyak instansi. Hal ini tentunya menyulitkan pengguna untuk melakukan pekerjaannya.

Sistem yang baik adalah sistem yang sudah bisa memenuhi kebutuhan-kebutuhan dan mampu mengatasi permasalahan yang ada dari sebuah sistem yang ada. Maka dari itu, pembangunan sistem yang baru ataupun pengembangan sistem yang sedang berjalan harus benar-benar sesuai dengan apa yang diharapkan oleh para penggunanya. Harapannya mulai dari kemudahan, kecepatan dan keakuratan dari informasi. Informasi menjadi sangat penting, jika informasi tersebut menyangkut pertimbangan untuk pengambilan keputusan. Maka dari itu sistem-sistem yang masih manual dan rumit harus di perbaiki. Salah satu sistem yang masih manual di Sekretariat DPRD Provinsi Jawa Barat yaitu proses pengarsipan kegiatan perjalanan dinas.

Sistem perjalanan dinas sangat penting karena nantinya berkaitan dengan laporan keuangan sebuah instansi. Oleh karena itu, data perjalanan dinas harus selalu tersimpan dengan baik di dalam basis data sebuah instansi pemerintahan.

Sesuai dengan Program Peningkatan Kapasitas Lembaga Pewakilan Rakyat Daerah yaitu Penguatan Peran dan Fungsi DPRD dalam Pembangunan dan Pemerintah dimana mewajibkan setiap Komisi DPRD melakukan kunjungan kerja perjalanan dinas ke berbagai daerah ataupun dalam rangka studi banding. Dengan banyaknya kegiatan perjalanan dinas, maka semakin banyaknya pula berkas-berkas 
kegiatan perjalanan dinas yang menumpuk dimana mengakibatkan rentan nya kehilangan data dan kurang efisien. Berdasarkan UU No. 32 Tahun 2004, UU 27 Tahun 2009, PP No. 41 Tahun 2007 dan Perda No. 20 Tahun 2008, Sekretariat DPRD adalah sebuah lembaga non departemen yang mempunyai tugas pokok menyelenggarakan dan mendukung tugas dan fungsi DPRD, serta menyediakan dan mengkoordinasikan tenaga ahli yang diperlukan oleh DPRD, melalui pendampingan perwakilan dari berbagai unit untuk setiap anggota DPRD yang melakukan perjalanan dinas.

Maksud dari pembuatan sistem ini, yaitu pembangunan sistem perjalanan dinas di Sekretariat DPRD Provinsi Jawa Barat. Adapun tujuan dari sistem tersebut adalah:

1. Mempermudah setiap Unit Kerja dan Kordinator dalam proses pembuatan Notadinas dan Surat Tugas.

2. Mempermudah setiap Pegawai dan Kordinator dalam proses pembuatan Surat Perintah Perjalanan Dinas.

3. Mempermudah Bagian Umum dan Administarsi serta Kordinator dalam pembuatan Bon, Kwitansi Pembayaran (Rincian Biaya dan Transportasi).

4. Mempermudah Bagian Umum dan Adminitrasi serta Bagian Keuangan dalam bentuk laporan bulanan pengontrolan Kendali Surat Perintah Perjalanan Dinas setiap Anggota DPRD dan Pegawai Negeri Sipil.

\section{KAJIAN PUSTAKA}

\subsection{Tinjauan Organisasi}

Sekretariat DPRD Provinsi Jawa Barat didasarkan kepada Peraturan Daerah Nomor 20, tentang Organisasi dan Tata Kerja Sekretariat Daerah dan Sekretariat DPRD Provinsi Jawa Barat, yang menyebutkan antara lain pada Pasal 5 bahwa, "Sekretariat merupakan unsur pendukung pelaksana tugas dan fungsi DPRD, Sekretariat DPRD di pimpin oleh Sekretaris, secara teknis operasional berada dibawah dan bertanggungjawab kepada Pimpinan DPRD dan administrasi bertanggungjawab kepada Gubernur melalui Sekretaris Daerah”.
Tugas pokok Sekretariat DPRD diatur pada Perda No. 20 Tahun 2008 dalam Pasal 6, yaitu "menyelenggarakan administrasi kesekretariatan, administrasi keuangan, mendukung pelaksanaan tugas dan fungsi DPRD sesuai dengan kemampuan keuangan daerah". Fungsi Sekretariat DPRD dalam melaksanakan tugas pokok antara lain :

1. Penyelenggaraan administrasi kesekretariatan DPRDP.

2. Penyelenggaraan administrasi keuangan daerah.

3. Penyelenggaraan rapat-rapat DPRD.

4. Penyelenggaraan dan penyediaan koordinasi tenaga ahli yang diperlukan DPRD.

Lebih lanjut tugas pokok dan fungsi tersebut menjadi tugas pokok dan fungsi yang melekat pada jabatan Sekretaris DPRD Provinsi Jawa Barat dengan rincian tugas sebagai berikut :

1. Menyelenggarakan penyusunan program kerja Sekretariat DPRD.

2. Menyelenggarakan administrasi rapat-rapat dan persidangan.

3. Menyelenggarakan administrasi dan analisa perundang-undangan.

4. Menyelenggarakan administrasi kehumasan dan keprotokolan.

5. Menyelenggarakan administrasi umum kerumahtanggan dan perjalanan dinas.

6. Menyelenggarakan administrasi keuangan.

7. Menyelenggarakan pengendalian dan pembinaan pegawai.

8. Menyelenggarakan penyedian tenaga ahli guna membantu kelancaran kegiatan DPRD.

9. Menyelenggarakan koordinasi dan dan fasilitasi kerjasama dengan unsure mitra kerja DPRD.

Berikut stuktur organisasi Sekretariat DPRD Provinsi Jawa Barat (lihat gambar 1). 


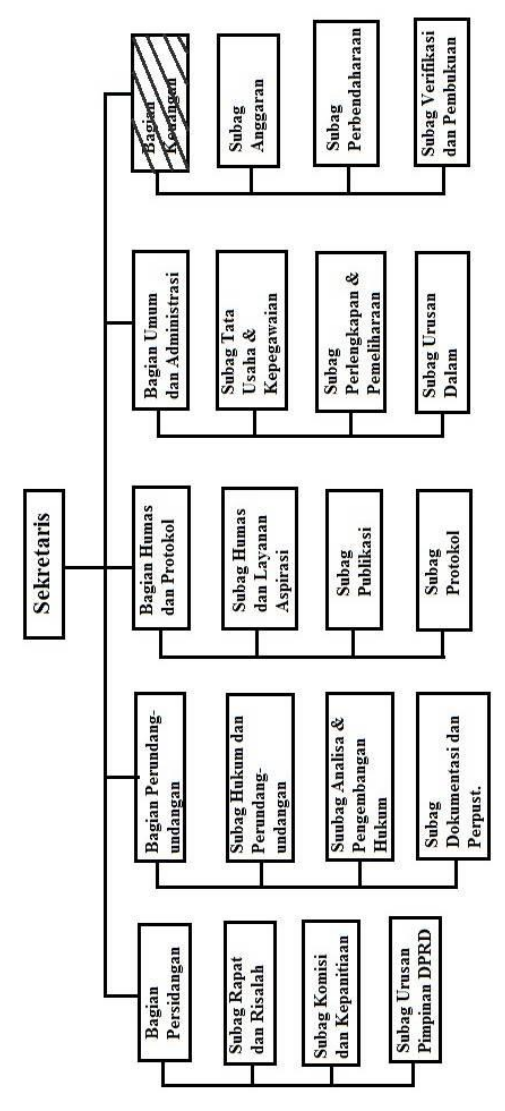

Gambar 1. Struktur Organisasi Perusahaan

\subsection{Pengertian Sistem Perjalanan Dinas}

Perjalanan dinas merupakan salah satu kegiatan Anggota DPRD dalam Program Peningkatan Kapasitas Lembaga Pewakilan Rakyat Daerah yaitu Penguatan Peran dan Fungsi DPRD dalam Pembangunan dan Pemerintah dimana mewajibkan setiap Komisi DPRD melakukan kunjungan kerja perjalanan dinas ke berbagai daerah ataupun $d$ alam rangka studi banding.

\subsection{Tujuan Perjalanan Dinas}

Adapun tujuan dari perjalanan dinas tersebut adalah sebagai berikut:

1. Untuk melihat banyaknya Anggota DPRD dan pendamping yang mengikuti perjalanan dinas.

2. Untuk memudahkan Pegawai Negeri Sipil dalam penyimpanan data-data perjalanan dinas.

Dengan diterapkannya Sistem Perjalanan Dinas dengan sendirinya telah membantu meningkatkan mutu dari instansi tersebut.

\subsection{Perangkat Lunak Pendukung}

\section{Pengertian PHP}

PHP singkatan dari Hypertext Prepocessor. Ia merupakan bahasa berbentuk skrip yang ditempatkan dalam server dan diproses di server. Hasil yang di kirimkan ke klien tempat pemakai menggunakan browser. PHP merupakan bahasa pemograman yang paling sering digunakan oleh programming web karena merupkan bahasa pemograman opensource, sehingga programming tidak perlu membuat lisensi untuk membuat aplikasi.

Secara khusus PHP dirancang untuk membentuk aplikasi web dinamis. Namun perlu diketahui bahasa PHP sebenarnya bisa dipkai secara command line yang dapat dijalankan tana melibatkan web server maupu dijalankan tanpa melinatkan web server maupun browser.

\section{Kelebihan PHP}

1. Bisa membuat web menjadi dinamis.

2. PHP bersifat open source yang berarti dapat digunakan oleh siapa saja secara gratis.

3. Aplikasi PHP lebih cepat dibandingkan dengan ASP maupun Java.

4. Mendukung banyak paket Database seperti MySQL, Oracle, PostgrSQL, dan lainlain.

5. Bahas apemograman PHP tidak memerlukan kompliasi / compile dalam penggunaannya.

6. Banyak web server yang mendukung PHP seperti apache, lighttpd, dan lain-lain.

7. Pengembangan aplikasi PHP mudah karena banyak dokumentasi, referensi dan developer yang membantu dalam pengembangannya.

\section{Kekurangan PHP}

1. PHP tidak mengenal package.

2. Jika tidak di encoding, maka kode PHP dapat dibaca semua orang dan untuk mengencodingnyadibutuhkan tool dari Zend yang mahal sekali biayanya.

3. PHP memiliki kelemahan keamanan, jadi programmer harus jeli dan berhati-hati dalam melakukan pemograman dan konfigurasi PHP.

\section{Pendukung PHP}

XAMPP merupakan perangkat lunak bersifat opensource yang bisa diunggah secara gratis dan bisa dijalankan di semua sistem operasi seperti Windows, Linux, Solaris, dan Mac dan XAMPP ini dibuat dan dikembangkan oleh Apache Friends. Perangkat lunak tersebut berisi kumpulan beberapa perangkat lunak yang 
dibutuhkan antara lain PHP, Apache, MySQL, dan PHPMyAdmin. Dengan melakukan instalasi XAMPP tersebut, maka semua perangkat lunak yang dibuthkan sudah otomatis terinstall di hardisk , termasuk pengaturan file-file yang diperlukan.

1. Apache merupakan web server yang bersifat opensource yang digunakan oleh PHP. Karena bersifat opensource sehingga bisa diambil, digunakan, bahkan bisa mengubah kode program tanpa harus membayar. Apache bertugas untuk menampilkan hasil proses script PHP yang ditulis oleh pembuat halaman web, sehingga dihasilkan halaman web yang benar kepada peminta dan database juga dapat diakses terlebih dahulu misalnya MsSQL diperlukan untuk mendukung.

2. MySQL merupakan database server yang paling digunakan dalam pemograman PHP. MySQL digunakan untuk mmenyimpan data di dalama database dan memanipulasi datadata yang diperlukan. Manipulasi data tersebut berupa menambah, mengubah, dan menghapus data yang berada dalam database..

3. PHP bersifat open source yang berarti dapat digunakan oleh siapa saja secara PHPMyAdmin membantu programming untuk memudahkan pengelolaan database dalam memanipulasi tabel karena tidak perlu menghafal sintaknya. Hal tersebut tentu cukup sulit jika kita harus menghafal semua baris sintak dan harus mengetikan satu persatu baris sintak tersebut.

Situs resmi dari aplikasi-aplikasi yang dijelaskan di atas terlihat pada tabel di bawah.

Tabel 1. Situs Resmi Perangkat Lunak Pendukung

\begin{tabular}{|l|l|}
\hline Perangkat Lunak & \multicolumn{1}{|c|}{ Alamat URL } \\
\hline Apache Server & http://www.apache.org \\
\hline MySQL & http://www.mysql.com \\
\hline PHP & http://www.php.net/ \\
\hline PHPMyAdmin & http://www.phpmyadmin.net \\
\hline
\end{tabular}

Untuk menghubungkan PHP dengan Database MySQL yang perlu disiapkan pertama kali yaitu aplikasi XAMPP karena dengan aplikasi tersebut bisa menggunakan laptop/PC menjadi sebuah server lokal. Tahap kedua yaitu membuat database nya memlalui PHPMyAdmin. Setelah membuat database maka diperlukan sebuah script yang ditulis biasanya menggunakan notepad, bisa di simpan dengan nama koneksi.php dengan isi script yaitu :

$<$ ?php

\$server = "localhost"; (nama host atau servernya)

\$username= "root"; (nama usernamenya)

\$password = " "; (password dari databse)

\$database = "tampildata"; (nama databasenya)

mysql_connect(\$server,\$username,\$password) or die ("gagal");

mysql_select_db(\$database) or die ("database tidak ditemukan");

?>

Untuk memanggil koneksi database di script yang dibutuhkan hanya cukup dengan menyimpan include "koneksi.php" di setiap script yang dibutuhkan.

\section{METODE PENELITIAN}

Dalam melaksanakan pencarian dan pengumpulan data, metode yang digunakan yaitu metode deskriptif analis. Metode ini yang bertujuan untuk menggambarkan dan menjelaskan keadaan instansi atau perusahaan berdasarkan data-data yang didapat, disertai dengan analisis-analisis sehingga memberikan gambaran yang jelas.

Teknik pengumpulan data yang digunakan :

1. Field Research (Observasi lapangan)

Melakukan tatap muka secara langsung ketempat objek penelitian, dimana ingin mengetahui keterlibatan personil yang berhubungan dengan sistem yang digunakan pada objek penelitian.

2. Interview (wawancara).

Melakukan wawancara kepada pihak perusahaan yang bersangkutan mengenai bagaimana sistem perjalanan dinas yang sedang berjalan di Sekretariat DPRD Provinsi Jawa Barat. Data apa saja yang diperlukan serta keterlibatan para staf dan pimpinan.

3. Library Research (penelitian pustaka). 
Cara pengumpulan data dengan membaca berbagai literatur yang berkaitan dengan pembuatan sistem dengan membaca dan mengumpulkan data yang diperlukan.

4. Pengumpulan data manual

Melakukan pengumpulan data secara langsung dengan meminta data fisik maupun soft kepada Pegawai yang berkepentingan dengan data tersebut.

\section{Metodologi Perancangan Sistem}

Metodologi yang digunakan dalam pembangunan aplikasi perjalanan dinas di Sekretariat DPRD Provinsi Jawa Barat adalah dengan menggunakan metode waterfall menurut referensi Sommerfille. Secara umum tahapan pada model dapat dilihat pada gambar di bawah ini :

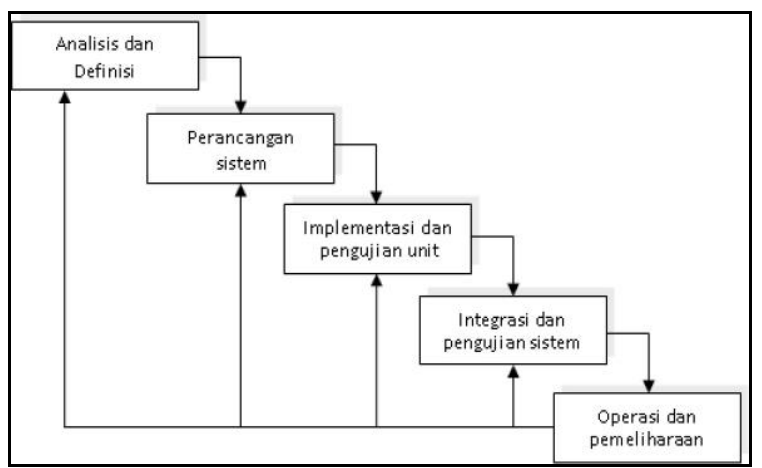

Gambar 2. Metode Perancangan Sistem (Sumber: menurut Sommerfille)

Gambar 2 di atas menujukan tahapan dari proses perancangan sistem. Penjelasan dari masingmasing tahapan yaitu :

1. Analisis dan Definisi merupakan proses menganalisis sistem dan mendefinisikan kebutuhan. Proses ini merupakan langkah awal dalam membuat sistem baru atau mengembangkan sistem yang lama. Dalam analisis sistem digunakan metode - metode yang telah dijelaskan pada point rancangan penelitian di atas, yaitu metode observasi lapangan, metode wawancara, penelitian pustaka dan pengumpulan data manual.

2. Perancangan Sistem, merupakan proses yang digunakan untuk mengubah kebutuhankebutuhan di atas menjadi representasi ke dalam bentuk "blue print"sebelum prosese coding dimulai. Desain harus dapat mengimplementa -sikan kebutuhan yang telah disebutkan pada tahap sebelumnya.
3. Implementasi dan Pengujian Unit, merupakan proses mengubah bentuknya menjadi bentuk yang dapat dimengerti oleh mesin, yaitu ke dalam bahasa pemrograman melalui proses coding. Tahap ini merupakan implementasi dari tahap design dan kemudian diuji perbagiaan atau unit.

4. Integrasi dan Pengujian Sistem, merupakan proses menggabungkan sub-sub sistem yang telah dibuat menjadi satu kesatuan sistem utama dan kemudian sistem tersebut diuji secara secara kesuluruhan.

5. Operasi dan Pemeliharaan, merupakan proses dioperasikannya sistem yang sudah dibuat dan diuji. Selama sistem tersebut dioperasikan, sistem harus dijaga dan dipelihara dengan benar agar tetap berjalan dengan baik.

Pada penelitian ini, tahap yang dilaksanakan dari metode perancangan sistem di atas hanya sampai tahap ke empat yaitu tahap integrasi dan pengujian sistem. Karena peneliti tidak memungkinkan untuk pengoperasian dan pemeliharaan sistem.

\section{HASIL DAN PEMBAHASAN}

\subsection{Deskripsi Sistem}

Sistem perjalanan dinas merupakan salah satu sistem di antara beberapa sistem yang terdapat di Sekretariat DPRD Provinsi Jawa Barat. Sistem ini keberadaannya sangat penting karena dapat menyimpan data-data surat. Setiap pegawai yang terlibat dalam proses pembuatan akan diberikan user untuk mengakses sistem ini.

Prosedur perjalanan dinas yang sedang berjalan untuk pegawai yaitu pertama setiap unit membuat notadinas yang ditandatangani oleh Kepala Sub Bagian masing-masing. Kemudian dibuatlah surat tugas oleh ajudan Kepala Bagian masingmasing dan yang ditandatangani serta dinomori oleh Bagain Umum. Setelah disetujui surat tugas maka dibuatlah SPPD untuk persyaratan membuat uang muka perjalanan dinas. Dibuatlah kwitansi perjalanan dinas rincian baik setiap pegawai yang melaksanakan perjalanan dinas dan kwitansi transportasi (Lihat Gambar 3).

Prosedur perjalanan dinas yang sedang berjalan untuk anggota dewan yaitu pertama setiap staff komisi membuat notadinas yang ditandatangani 
oleh Ketua Komisi masing-masing dan dinomori oleh Bagian Persidangan. Kemudian dibuatlah surat tugas oleh ajudan Kepala Ketua Dewan dan yang ditandatangani serta dinomori oleh Bagain Umum. Setelah disetujui surat tugas diberikan kepada staff keuangan sebagai koordinator perjalanan dinas, maka dibuatlah SPPD untuk persyaratan membuat uang muka perjalanan dinas. Dibuatlah kwitansi perjalanan dinas rincian baik setiap anggota dewan yang melaksanakan perjalanan dinas dan kwitansi transportasi (Lihat Gambar 4).

Berikut ini deskripsi sistem perjalanan dinas di Sekretariat DPRD Provinsi Jawa Barat dengan menggunakan Activity Diagram:

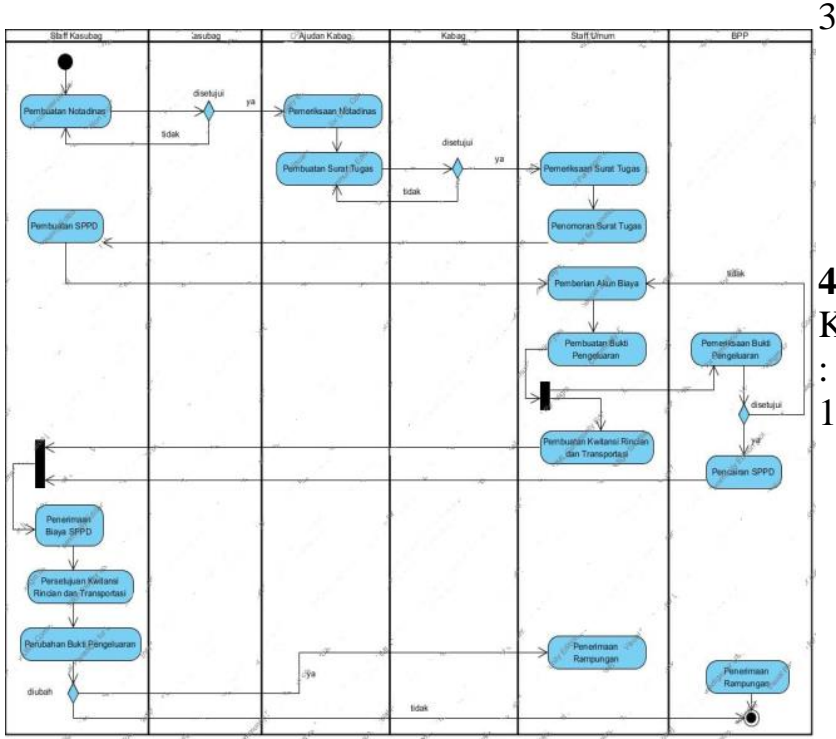

Gambar 3. Activity Diagram Pegawai Sistem Perjalanan Dinas

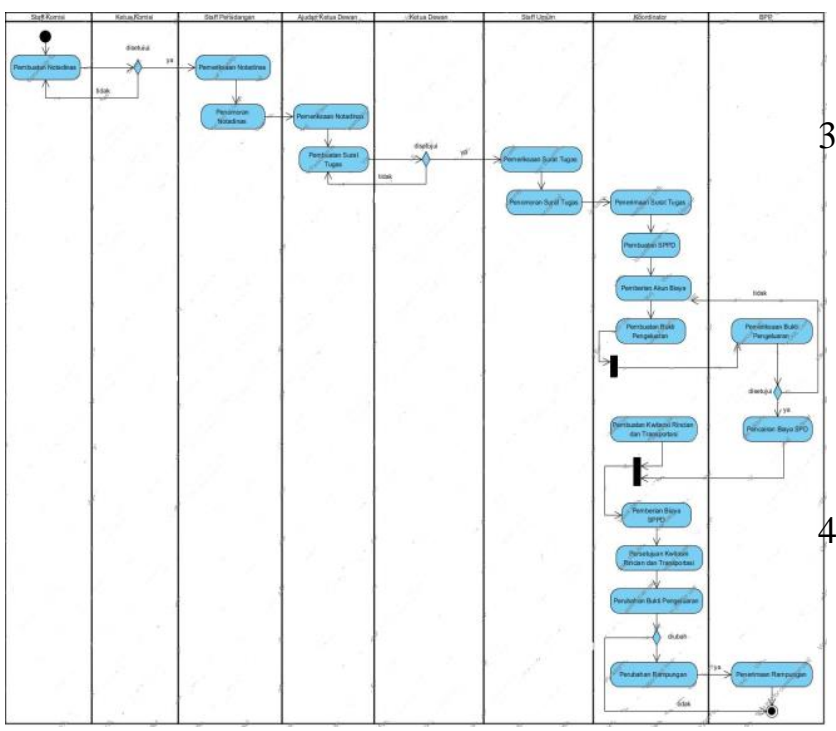

\section{Gambar 4. Activity Diagram Dewan Sistem} Perjalanan Dinas

\subsection{Analisis Masalah}

Sistem perjalanan dinas di Sekretariat DPRD Povinsi Jawa Barat selama berjalan mempunyai beberapa masalah atau kendala yaitu :

1. Proses pembuatan pemberkasan masih dilakukan secara manual.

2. Keterlambatan dalam pengolahan data karena walaupun sudah menggunakan komputer dengan program Microsoft Word dan Microsoft excel, tetapi masih membutuhkan proses yang lama dalam input data. Hal ini mengakibatkan terlambatnya informasi yang dibutuhkan oleh pegawai tahap selanjutnya.

3. Sering terjadi kesalahan dalam input data, perhitungan jumlah keseluruhan rekap berkas perjalanan dinas dan berakibat kesalahan dalam pemberian tunjangan biaya perjalanan dinas (tidak sesuai dengan pagu).

\subsection{Analisis Kebutuhan}

Kebutuhan yang diharapkan oleh pengguna yaitu

Functional requirement (kebutuhan yang terkait dengan fungsi produk ).

Fungsi yang dibutuhkan dalam sistem perjalanan dinas yaitu pembuatan notadinas, pembuatan surat tugas, pembuatan sppd, pembuatan bukti pengeluaran, pembuatan kwitansi rincian, pembuatan kwitansi transportasi, login, pengelolaan sistem perjalanan dinas, dan verifikasi.

2. Development requirement (Kebutuhan yang terkait dengan tools baik hardware atau software). Sistem perjalanan dinas dapat dikembangkan menggunakan bahasa PHP dan MySQL.

3. Deployment requirement (Kebutuhan terkait dengan lingkungan dimana Sistem Informasi akan digunakan baik hardware atau software).

Sistem perjalanan dinas harus mampu berjalan pada server dengan spesifikasi perangkat keras memory $5 \mathrm{~GB}$, processor Intel ${ }^{\circledR}$ Core $^{\mathrm{TM}}$ i5 CPU, dan menggunaka Sistem Operasi Linux.

4. Performance requirement (Kebutuhan yang terkait dengan ukuran kualitas maupun kuantitas, khususnya kecepatan, skalabilitas dan kapasitas).

a. Sistem pengelolaan perjalanan dinas mampu menyimpan data 1000 orang 
karena di dalam development requirement dibutuhkan pengelolaan MySQL.

b. Kecepatan dalam proses membuat berkas-berkas yang dapat mengurangi waktu pembuatan.

c. Mampu menghitung kalkulasi dan menampilkan rincian biaya secara otomatis dari tujuan perjalanan dinas yang ditentukan.

5. Documentation requirement (terkait dengan dokumen apa saja yang disertakan pada produk akhir).

Penggunaan sistem disertai dengan dokumen teknis penggunaan sistem tersebut. Di dalam dokumen dibahas juga tentang siapa saja pengguna (aktor) yang menggunakan sistem perjalanan dinas.

\subsection{Analisis Pengguna}

Analisis user atau pengguna sistem sedang berjalan yaitu : Staff Kasubag, Kasubag, Ajudan Kabag, Kabag, Staff Umum, BPP, Staff Komisi, Ketua Komisi, Staff Persidangan, Ajudan Ketua Dewan, Ketua Dewan, Koordinator termasuk kedalam Nä̈ve user karena pemakai tidak berpengalaman, berinteraksi dengan system tanpa menulis program, tinggal menjalankan satu menu sesuai dengan kebutuhan.

\subsection{Analisis Perangkat}

Proses perajalanan dinas di Sekretariat DPRD Provinsi Jawa Barat menggunakan sebuah mesin komputer yaitu hardware dan software. Kriteria hardware paling dasar yaitu processor minimal 3.2 GHz. Kriteria software paling dasar menggunakan program office yaitu Microsoft Word dan Microsoft Excel.

Berdasarkan analisis yang telah dijalankan di atas dapat diambil kesimpulan bahwa Sekretariat DPRD Provinsi Jawa Barat untuk hardaware telah memenuhi kebutuhan sistem, tetapi untuk software belum membutuhkan sistem yang mampu mangatasi masalah-masalah yang ada. Maka dibuatlah perancangan sistem perjalanan dinas.

\subsection{Perancangan Sistem}

Perancangan sistem adalah upaya untuk mengkonstruksi sebuah sistem yang memberikan kepuasan (mungkin informal) terhadap spesifikasi kebutuhan fungsional, memenuhi target, kebutuhan secara implisit atau eksplisit dari segi performansi maupun penggunaan sumber daya, kepuasan batasan pada proses desain dari segi biaya, waktu dan perangkat.

\section{Use Case Diagram}

Perancangan awal sistem menggunakan uses diagram. Berikut di bawah ini uses case diagram untuk sistem perjalanan dinas:

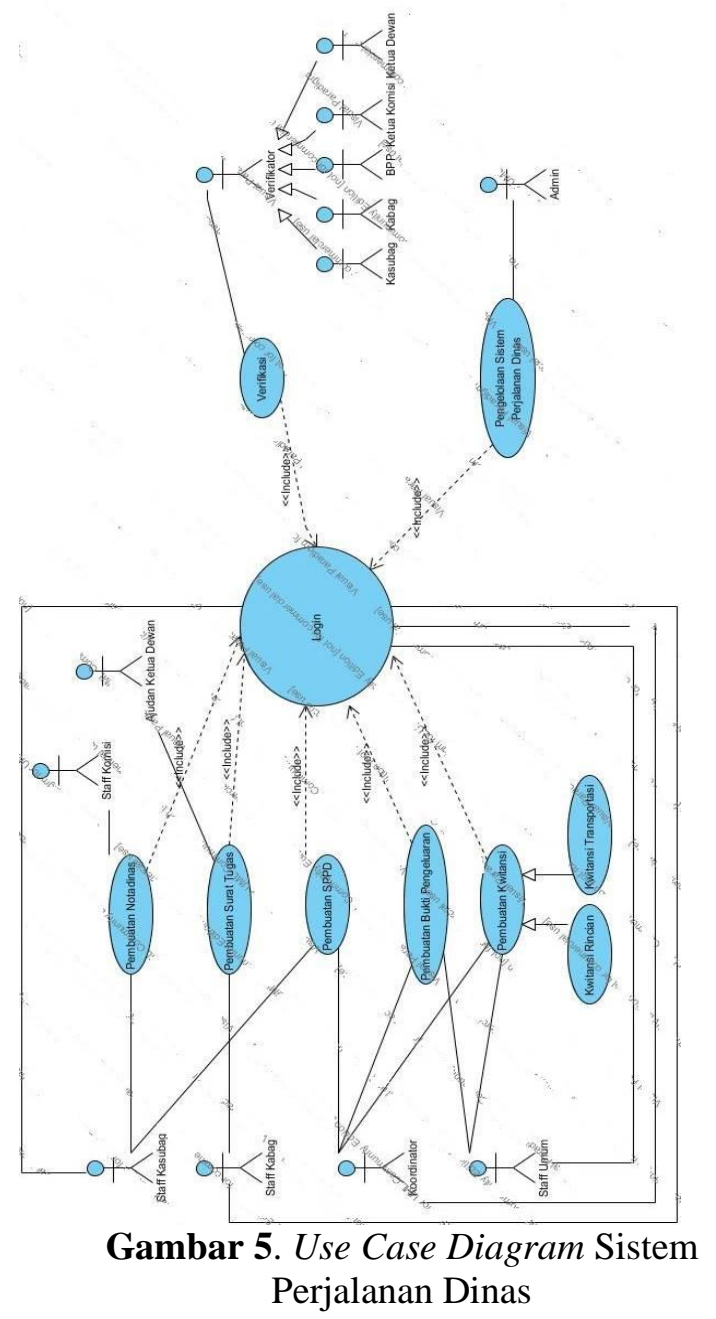

Class Diagram

Berikut di bawah ini adalah class diagram sistem perjalanan dinas : 

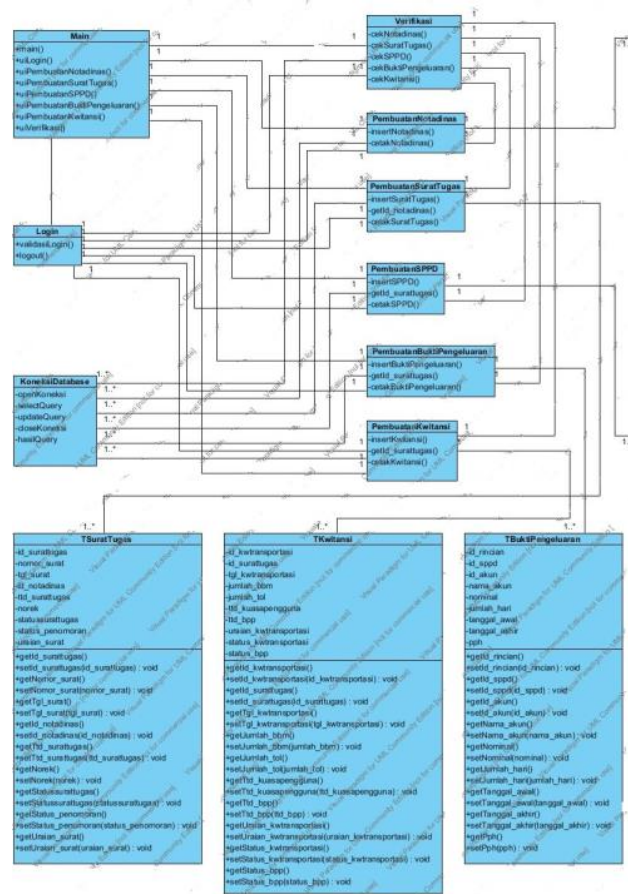

Gambar 6. Class Diagram Sistem Perjalanan Dinas.

\section{Sequence Diagram}

Berdasarkan diagram use case pada gambar 5, disusunlah sequence diagram setiap use case berikut ini (dapat dilihat dari gambar 7 sampai gambar 16):

1. Sequence Diagram Pembuatan Notadinas
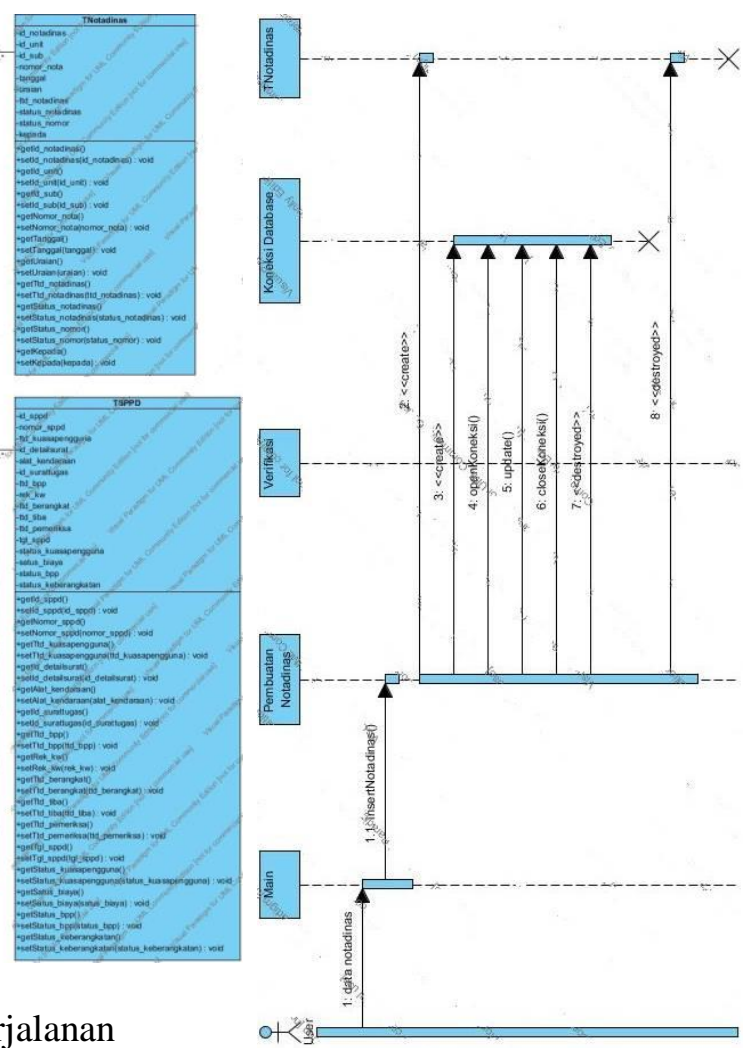

Gambar 7. Sequence Diagram Pembuatan Notadinas

2. Sequence diagram Pembuatan Surat Tugas

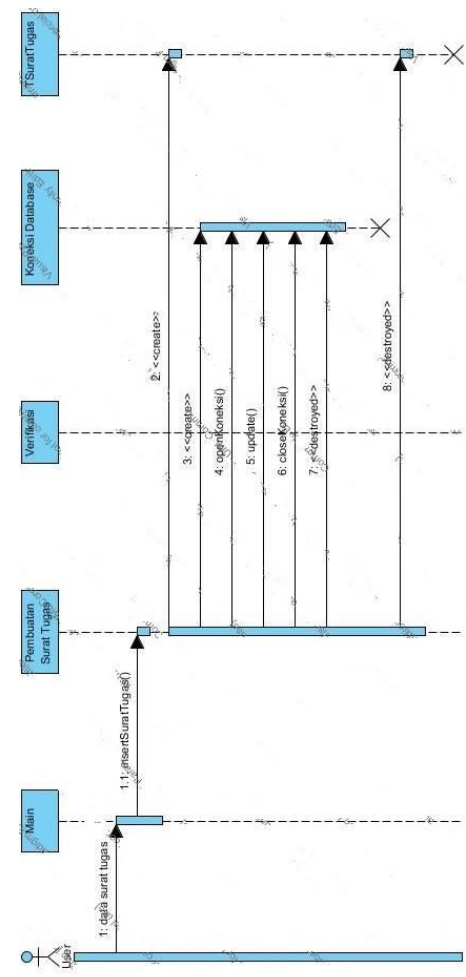


Gambar 8. Sequence Diagram Pembuatan Surat Tugas

3. Sequence Diagram Pembuatan SPPD

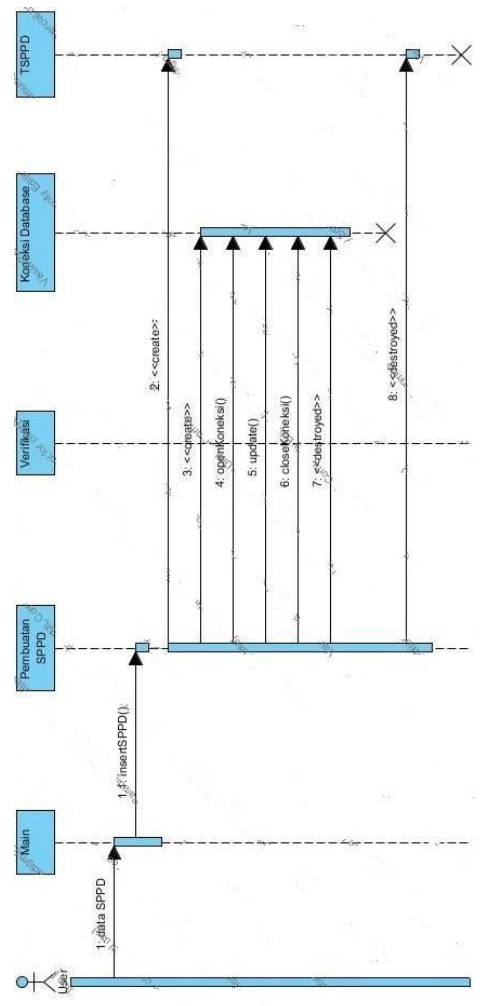

Gambar 9. Sequence Diagram Mengelola Data Presensi dan Transport

4. S equence diagram Pembuatan Bukti Pengeluaran

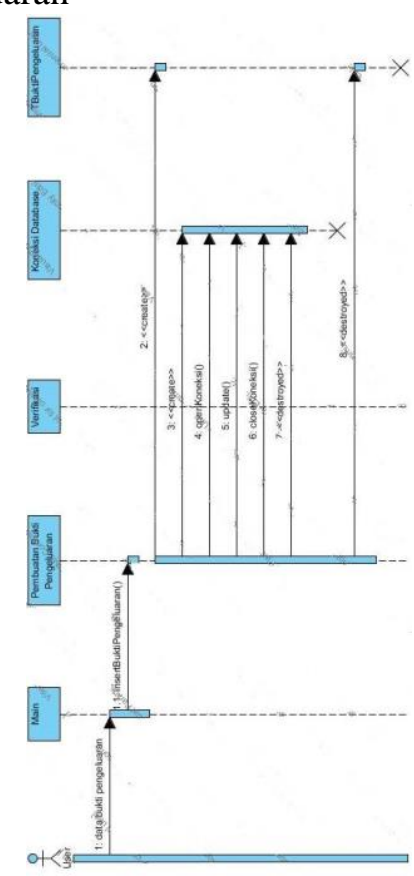

Gambar 10. Sequence Diagram Pembuatan Bukti Pengeluaran

5. Sequence diagram Kwitansi

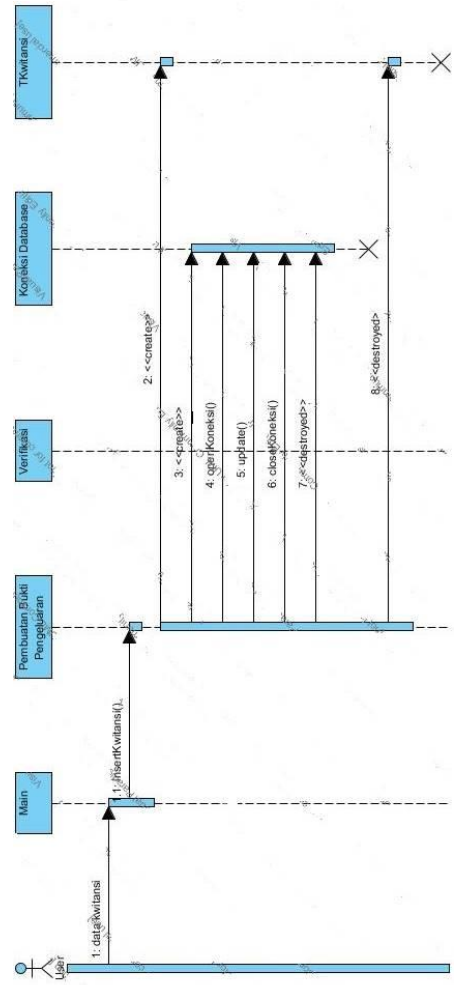

Gambar 11. Sequence Diagram Kwitansi

6. Sequence diagram Verifikasi Notadinas

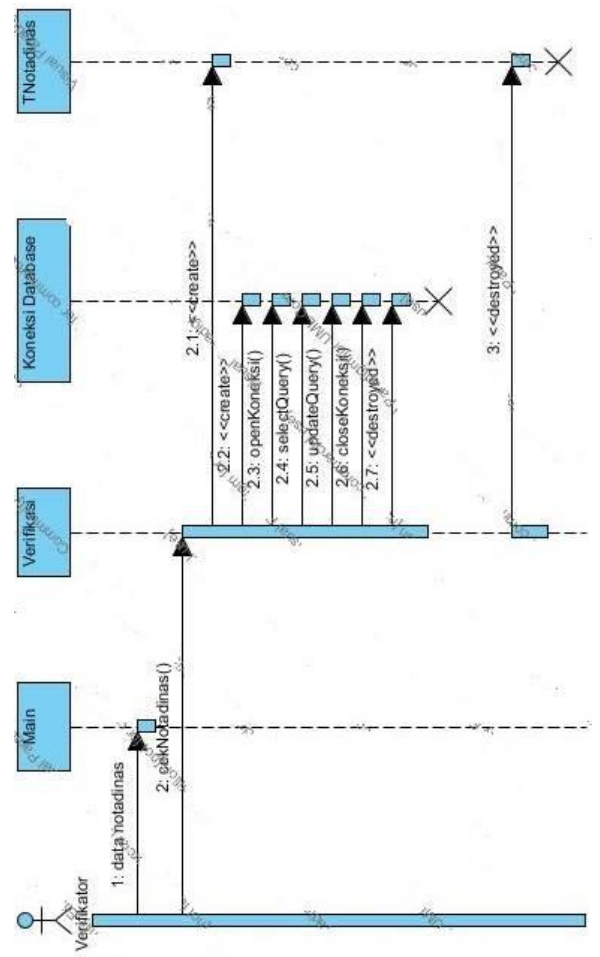

Gambar 12. Sequence Diagram Verifikasi Notadinas 
Gambar 14. Sequence Diagram Verifikasi SPPD

7. Sequence diagram Verifikasi Surat Tugas

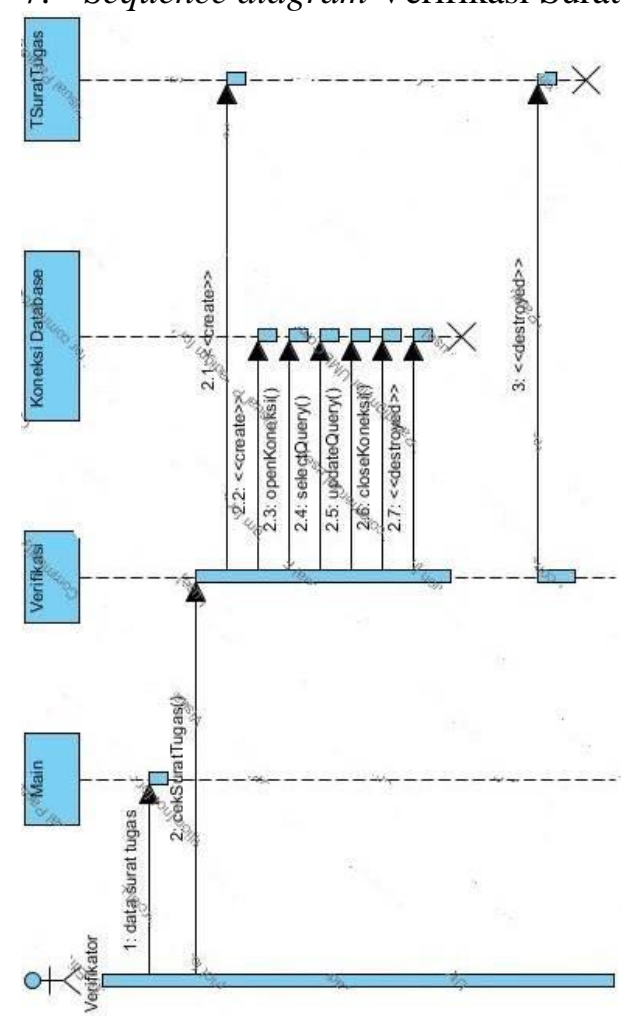

Gambar 13. Sequence Diagram Verifikasi Surat Tugas

8. Sequence diagram Verifikasi SPPD

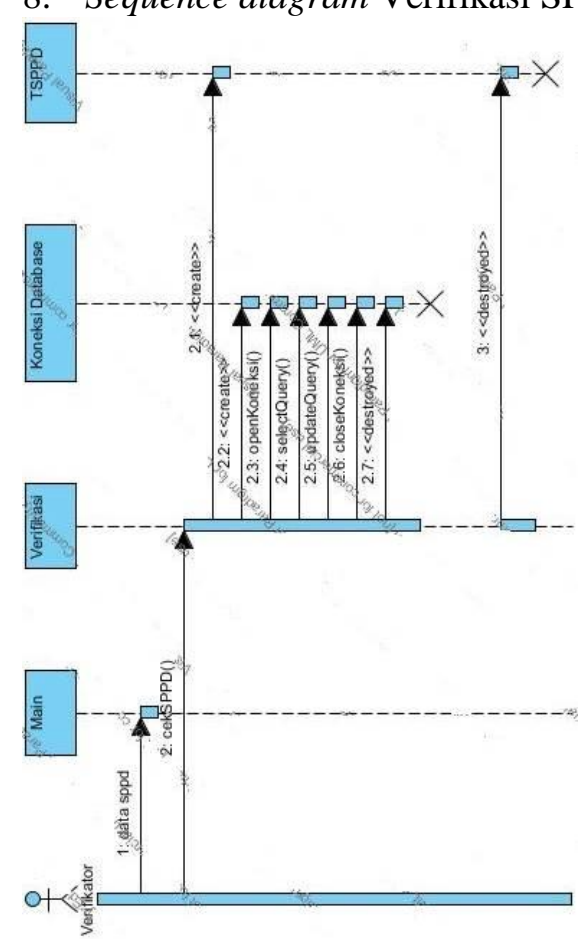

9. Sequence diagram Verifikasi Bukti Pengeluaran

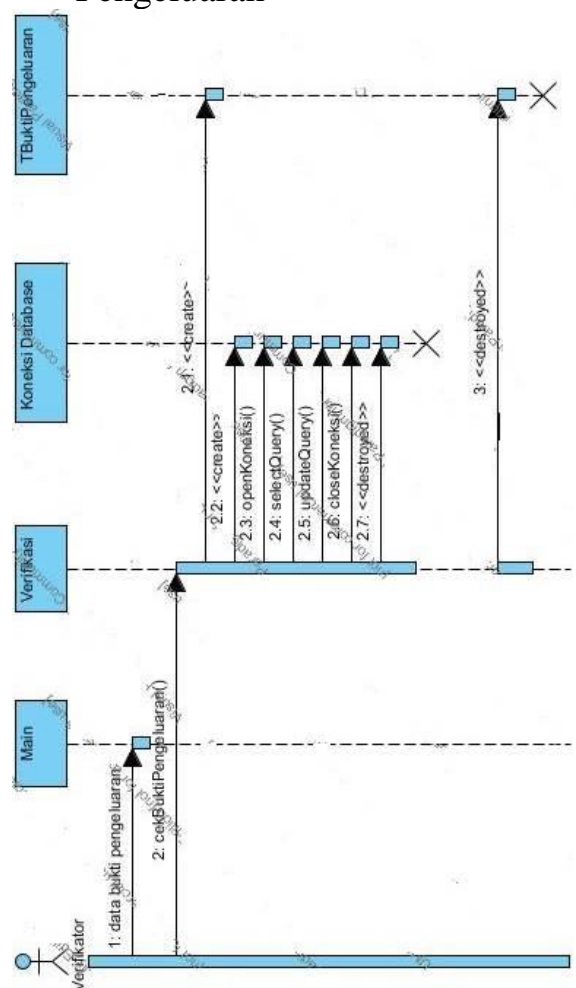

Gambar 15. Sequence Diagram Verifikasi Bukti Pengeluaran

10. Sequence diagram Verifikasi Kwitansi

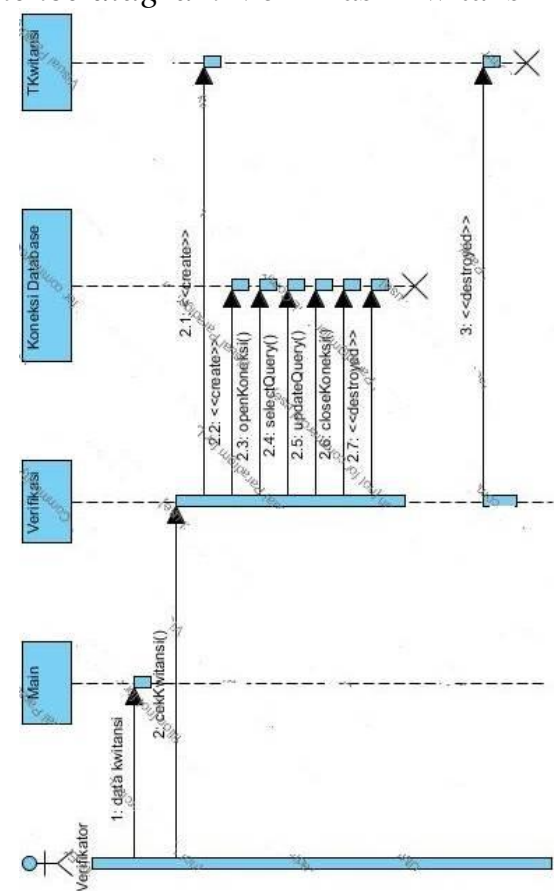


Gambar 16. Sequence Diagram Verifikasi Kwitansi

\subsection{Implementasi Sistem}

Implementasi sistem merupakan tahapan dalam pengembangan sistem setelah perancangan. Di tahap ini, hasil rancangan diterapkan ke dalam bahasa pemrograman. Secara garis besar, sistem yang dibangun dapat digambarkan dalam deployment diagram pada gambar 17 berikut ini:

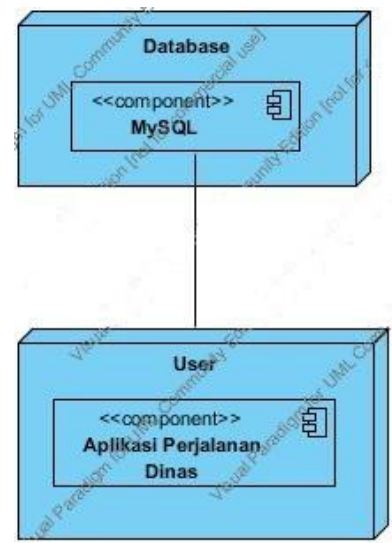

Gambar 17. Deployment Diagram Sistem Perjalanan Dinas

Sedangkan beberapa coding dapat dilihat sebagai berikut:

1. Membuat Notadinas

Rincian script atau coding berada di Listing Program.

Berikut hasil dari pengkodingan diatas, tampilannya dapat dilihat pada gambar 18 berikut ini.

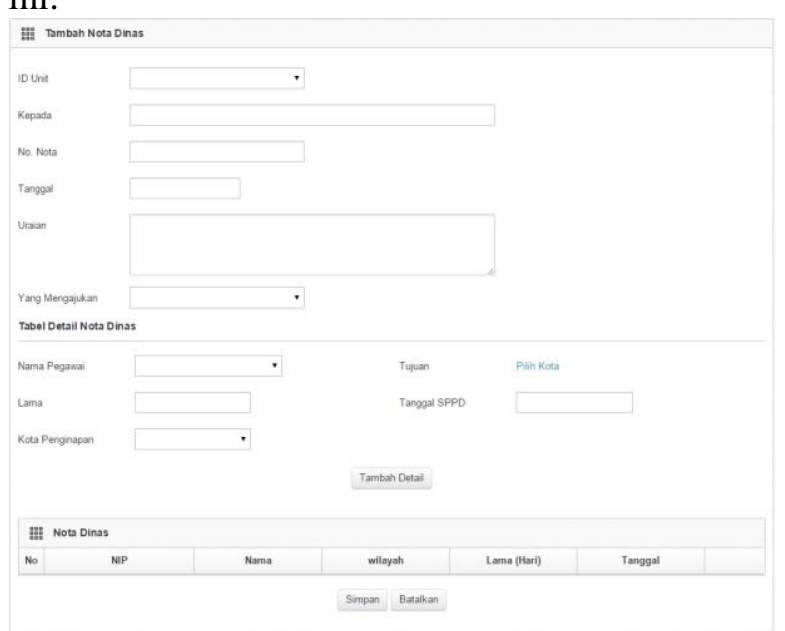

Gambar 18. Tampilan Membuat Notadinas

2. Membuat Surat Tugas

$\langle$ div class="row-fluid">
$<$ h3 $>$ Tambah Nota Dinas $</$ h3 $>$

$<$ span $>$ Tambah Nota Dinas $</$ span $>$

$<$ php

if (\$_SESSION['SesiIDUnit'] !=0)\{

combo_box("SELECT * FROM unit_kerja WHERE id_unit = "'. \$_SESSION['SesiIDUnit'] ."'", 'id_unit', 'id_unit',

'nama_unit', \$id_unit, 'submit();', 'none', 'class="span3"');

\} else \{

combo_box("SELECT * FROM unit_kerja", 'id_unit', 'id_unit', 'nama_unit', \$id_unit, 'submit();', ", 'class="span3"'); \}

?>

$<$ ?php

\$hitung_idsub $=$ mysql_num_rows $($ mysql_query("SELECT *

FROM sub WHERE id_unit = '\$id_unit'"'));

if (\$hitung_idsub >0) \{

if (\$_SESSION['SesiIDSub'] !=0)\{

?>

$<$ div class="form-row row-fluid" >

$\langle$ div class="span12" >

$<$ div class="row-fluid" $>$

$<$ label class="form-label span2" for="normal" style="textalign: left" $>$ ID Sub $</$ label $>$

$<$ ?php combo_box("SELECT * FROM sub WHERE id_unit = '\$id_unit' and id_sub = "'. \$_SESSION['SesiIDSub'] ."'", 'id_sub', 'id_sub', 'nama_sub', \$id_sub, 'submit();', 'none', 'class="span3"');?>

\} else \{

echo dateIndo(\$row['tglsppd']);

\}

$<$ div class="span12" >

$<$ div class="box" >

$\langle$ div class="title" >

$<\mathrm{h} 4>$

$<$ span class="icon16 brocco-icon-grid" $></$ span $>$

$<$ span $>$ Tambah Surat Tugas $</$ span $>$

$<$ ?php

if $\left(\$ \_\right.$SESSION['SesiIDUnit'] == '1')

combo_box("SELECT * FROM nota_dinas WHERE

id notadinas IN (\$sudahdibuat) AND nota_dinas.id_unit IN ('2', '3', '4', '5', '6') AND nota_dinas.id_sub = '0'",

'id_notadinas', 'id_notadinas', 'nomor_nota', \$id_notadinas,

'submit();', ", 'class="span3"');

\} else if $\left(\$ \_\right.$SESSION['SesiIDUnit'] == '7') \{

combo_box("SELECT * FROM nota_dinas WHERE

id_notadinas IN (\$sudahdibuat) AND nota_dinas.id_unit IN ('1', '8', '9', '10', '11', '12', '13', '14', '15', '16') AND

nota_dinas.id_sub = '0'", 'id_notadinas', 'id_notadinas',

'nomor_nota', \$id_notadinas, 'submit();', ", 'class="span3"');

\} else if (in_array(\$_SESSION['SesiIDUnit'], array('13', '14', '15', '16')) == TRUE) \{

// LOGIN KETUA DEWAN \& AJUDAN

combo_box("SELECT * FROM nota_dinas WHERE

id_notadinas IN (\$sudahdibuat) AND nota_dinas.id_unit IN

('7') AND nota_dinas.id_sub = '0'", 'id_notadinas',

'id_notadinas', 'nomor_nota', \$id_notadinas, 'submit();', ", 'class="span3"');

\} else if (\$_SESSION['SesiIDUnit'] !=0)\{

combo_box("SELECT * FROM nota_dinas WHERE

id_notadinas IN (\$sudahdibuat) AND nota_dinas.id_unit =

"'.\$_SESSION['SesiIDUnit']."' AND nota_dinas.id_sub !=

'0'", 'id_notadinas', 'id_notadinas', 'nomor_nota', 
\$id_notadinas, 'submit();', ", 'class="span3"');

\} else \{

combo_box("SELECT * FROM nota_dinas WHERE id_notadinas IN (\$sudahdibuat)", 'id_notadinas', 'id_notadinas', 'nomor_nota', \$id_notadinas, 'submit();', ", 'class="span3"'); \}

Rincian script atau coding berada di Listing Program.

Gambar 19 berikut merupakan hasil dari pengkodingan di atas :

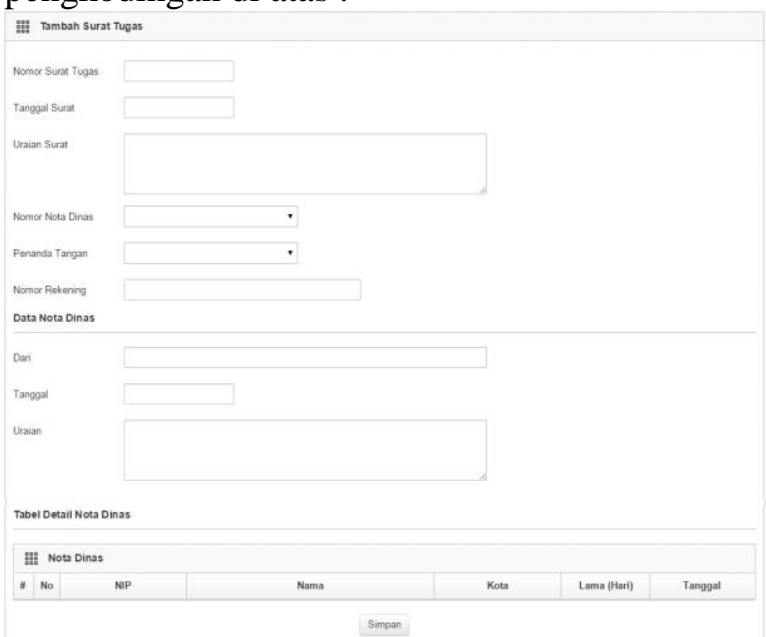

Gambar 19. Tampilan Membuat Surat Tugas

\section{PENUTUP}

Berdasarkan hasil dari analisis sistem perjalanan dinas yang sedang berjalan di Sekretariat DPRD Provinsi Jawa Barat, instansi pemerintahan ini membutuhkan pembangunan sistem yang bisa menyelesaikan masalah-masalah di atas dan juga dapat memenuhi kebutuhan-kebutuhan yang diperlukan. Sistem ini akan menghasilkan ouput berupa report bulanan dari SPPD yang melaksanakan perjalanan dinas berupa Kendali Anggota. Membantu PNS (Pegawai Negeri Sipil) dalam pengelolaan data tersebut menjadi lebih mudah, cepat dan akurat dalam pengerjaannya. Membantu bagian Umum dan Administrasi serta bagian Keuangan menentukan tindakan terhadap pegawai nya berdasarkan report bulanan Kendali Anggota. Tindakannya berupa pemberian teguran, harus seimbang dengan rekan kerja yang lain dalam memfasilitasi perjalanan dinas. Kesimpulan dari pembangunan sistem di atas, membuat sistem perjalanan dinas yang dapat mengurangi kecurangan dan membantu PNS (Pegawai Negeri Sipil) dalam pengelolaan data presensi di Sekretariat DPRD Jawa Barat.
Sistem perjalanan dinas yang dibangun pada penelitian ini, masih dapat dikembangkan lagi seiring dengan kebutuhan penggunanya. Berikut adalah beberpa saran dari pengembangan yang dapat dilakukan :

1. Penambahan dashboard menampilkan jadwal perjalanan dinas yang akan dilakukan selanjutnya.

2. Penambahan penilaian kinerja perjalanan dinas untuk membantu BPK (Badan Pengawas Keuangan) dalam pemeriksaannya.

\section{DAFTAR PUSTAKA}

[1] Simarmata, Janner. 2010. Rekayasa Perangkat Lunak. Jakarta : Andi publisher

[2] Ramadhan, Arief. 2006. Pemograman Web Database dengan PHP dan MySQL. Jakarta: PT. Elex Media Komputindo.

[3] Kurniawan, Fajar. 2007. Kebutuhan TI dan Aplikasi Berbasis Web. Jogjakarta: teknologi informasi.

[4] Suhendar, A., Gunadi, Hariman.2002. Visual Modeling dan UML dan Rational Rose.Bandung:Informatika Bandung.

[5] Sutopo, Ariesto Hadi.2002. Analisa dan Desain Berorientasi Objek .2002. Yogyakarta: J\&J Learning. 